\title{
Mutual Fund Industry in Pakistan
}

\section{Amjad Waheed*}

Pakistan experienced the reverberations starting in 1988 of the changes that swept the Asian emerging markets. To create an investment friendly environment the GoP adopted liberal economic policies of deregulation, privatisation, opening of capital markets to foreigners, liberalisation of foreign exchange regulations and dismantling of investment contro1 - policies that lead to a significant increase in direct and indirect foreign investment in the country.

These changes resulted in a drastic increase in the financial assets of Pakistan with stock market capitalisation rising from Rs.188 bn in 1991 to Rs. 547 bn at present, daily trading volume improving from $2 \mathrm{mn}$ shares in 1991 to $50 \mathrm{mn}$ shares at present and number of listed companies rising from 542 in 1991 to 788 at present.

Despite the global trend of a significant increase in financial assets and the surge in domestic market capitalisation, an average Pakistani investor is still skeptical about entering the market. The reasons for this skepticism are:

- lack of information about capital markets.

- inherent risk involved in investing in stocks.

Therefore, it is crucial for an ordinary investor to understand the way in which to overcome these drawbacks. An efficient and a risk averse mode of doing this is by investing in a mutual fund. A mutual fund is simply a group of stocks and other financial assets managed by trained investment professionals. Such a fund offers its shares to the public who in turn, become its owners. Typically, the fund advisor uses investors' money to acquire stocks and bonds within the legal framework of the Corporate Law Authority. In other words, investors invest in a mutual fund to purchase a single portfolio (a portfolio is a basket of stocks).

\section{Why Invest in a Mutual Fund?}

\section{Cost Efficiencies}

The operating costs of a fund manager are lower due to the economies of scale of managing large portfolios. Mutual fund

\footnotetext{
${ }^{*}$ The author is the chief Operating Officer of first Capital Mutual Fund.
} 
management can save on accounting fees, research costs, and brokerage fees, etc., due to the availability of a relatively large pool of resources. For example, the cost of managing a single Rs.1OOmn portfolio is less than the cost of managing 500 portfolios of Rs.200,000 each. Not only are costs lower, professional managers are less likely to make bad investment decisions by investing too much in a single security.

\section{Expert Management}

Due to paucity of knowledge, an average investor does not feel confident enough to decide which securities to invest in, a condition made worse as investment advisory services are not available to most investors nor are they familiar with this concept. Mutual fund managers are trained investment professionals whose knowledge can provide greater risk adjusted returns. Successful timing and selection of stocks by mutual fund managers can maximise shareholder returns which investors may not be able to achieve on their own. The method of stock valuation and selection is a scientific process for which professionals use technical and fundamental analysis to identify stocks that have the best prospect of value appreciation.

Technical analysis entails scrutinising the historical stock price and volume movements that help in identifying price patterns to assist in the forecast of future prices. Fundamental analysis, on the other hand, is based on the study of economic data such as earning prospects, dividends, product risk, return on equity, profit margin, expected growth rate in earnings, financial conditions, market share, patent protection etc., of a company to calculate its intrinsic value. This intrinsic value is then compared with the current market value of the stock to make buy, sell, or hold decisions. Usually, an average investor does not have the time or the expertise, as opposed to fund managers, to keep abreast of all the micro and macro changes affecting stock prices.

\section{Risk Diversification}

Investors are averse to huge fluctuations in stock prices. A mutual fund can stave off this barrier by providing broad diversification through the pooling of resources, a possibility not available to an individual investor. The portfolio theory suggests that as an investor spreads his/her investment over a large number of stocks, the investment risk goes down. Stock prices of various companies are less then perfectly correlated. Therefore, adding stocks that are not 
highly correlated with each other results in a reduction of portfolio risk.

Investment risk arises from two sources - company risk and market risk. Company risk purports that something 'bad' will happen to the company, therefore, its stock price will fall. This may be due to poor management of the company, a natural disaster such as fire or storm, human error, drop in demand of the product, etc. Company risk effects only one particular firm or industry but not all the stocks in the market.

Examples of company risk are Taj Company and Mohib Textiles where companies failed because of poor management resulting in huge losses to investors. Another example is that of Union Carbide, whose plant exploded in India in 1984, leaving thousands of people dead and disabled. Yet another example is the oil spill in Alaska where Exxon ended up paying billions of dollars to clean up the mess. Stock prices did not fall drastically in the case of Union Carbide or Exxon as both companies had huge reserves to safeguard against such accidents.

Company risk can be reduced or even eliminated by owning a large number of stocks in the portfolio. If an investor holds a large number of stocks in the portfolio, and some of these companies do not perform well, it will not affect the overall returns significantly. Financial analysts suggest that company risk can be reduced drastically if an investor holds about 40 stocks in his/her portfolio. Since it is difficult for an average investor with limited resources to own and keep track of so many different stocks, investors can reduce investing in a mutual fund.

Market risk affects the entire range of stocks through such variables as interest rates, inflation, budget deficits, government regulations, taxes, political and economic situation of the country, war, recession etc., but some companies tend to suffer more than others. For example, during a recession companies that deal in consumer goods such as cars get more affected than those that deal in necessities. This is because during a recession people may postpone buying durables like a washing machine or a car but they do not postpone eating food or taking medicine. Mutual fund managers hold stocks that they feel have less market risk when they expect a recession or a downfall in the stork market- for some reason. 


\section{Development of Capital Markets}

Mutual funds also help in the development of capital markets. An average Pakistani investor is afraid of manipulation by either the management of a company or by speculators who may affect the stock price of a particular company through volume buying or selling of stock. However, in the presence of a large number of mutual funds it becomes difficult for speculators who generally hold large blocks of issues to impact stock prices. For example, if the intrinsic value of a stock is Rs 50 and speculators start lowering the price by selling off a large quantity of the stock, then mutual fund managers who know the intrinsic value of the stock will start buying the stock, at the same time thereby reducing the effect of selling pressure to some extent.

In conclusion, mutual funds help build the confidence of an average investor to invest in the stock market. Simultaneously, they help keep the stock market efficient as managers continuously identify undervalued and overvalued stocks and therefore carry out a balancing act by transacting in them.

\section{Mutual Fund Industry in Pakistan}

The largest mutual fund in Pakistan is government-owned NIT with total market value of the fund estimated at Rs $30 \mathrm{bn}$. It is the only open-end fund in Pakistan although recently the government has allowed the private sector to start open-ended funds as well. ICP is the second largest mutual fund with total market capitalisation of all its funds ofRs7.8bn. There are 14 private mutual funds as well with total market capitalisation ofRs1.6bn. The private mutual funds have suffered due to two main reasons:

- Most of them started operations in 1994 and 1995 when the stock market was at a peak and have suffered because of a significant drop in stock prices since then.

- These funds trade at a 50 per cent discount to their NAV that has eroded investor confidence in them (see Table I below). I Table I: Mutual Fund Industry in Pakistan 
Table 1: Mutual Fund Industry in Pakistan

as on 30th September 1997

\begin{tabular}{lrrrr}
\multicolumn{1}{c}{ Company Name } & $\begin{array}{c}\text { Paid up Capital } \\
\text { (Rs. M) }\end{array}$ & $\begin{array}{c}\text { NAV } \\
\text { Rs./shr. }\end{array}$ & $\begin{array}{c}\text { Mkt Price } \\
\text { (Rs.) }\end{array}$ & $\begin{array}{c}\text { Prem/Dis } \\
\text { (\% age) }\end{array}$ \\
\hline A1-Meezan Mutual Fund & 250.00 & 10.91 & 8.22 & -25 \\
\hline Asian Stock Fund & 100.00 & 7.38 & 4.00 & -46 \\
BSJS Balanced Fund & 150.00 & 12.42 & 7.50 & -40 \\
Confidence Mutual Fund & 100.00 & 11.59 & 4.50 & -61 \\
Dominion Stock Fund & 50.00 & 8.38 & 1.35 & -84 \\
First Capital Mutual Fund & 150.00 & 7.89 & 2.00 & -75 \\
Golden Arrow & 81.50 & 4.13 & 1.95 & -53 \\
Growth Mutual Fund & 100.00 & 4.18 & 1.20 & -71 \\
KASB Premier Fund & 400.00 & 8.26 & 2.50 & -70 \\
Prudential Stock Fund & 60.00 & 4.60 & 1.55 & -66 \\
Safeway Mutual Fund & 30.00 & 4.50 & 4.90 & 9 \\
Security Stock fund & 100.00 & 10.55 & 4.65 & -56 \\
Tri-Star Mutual Fund & 50.00 & 3.53 & 1.90 & -46 \\
& $\mathbf{1 , 6 2 1 . 5 0}$ & & & \\
\hline
\end{tabular}

Source: Mutual Fund Association of Pakistan.

\section{Net Asset Value of a Mutual Fund}

Net asset value is estimated by multiplying the number of shares I each company held in the portfolio by its respective current market price and summing them. Funds expenses are then subtracted from this amour and the net asset value is divided by the total number of units (shares) of the fund.

To illustrate, assume a fund raises Rs.1OO.OOO from investors by offering 10,000 shares at Rs.1O each. It buys 1,000 shares each of Hubco and PTC for the total amount of Rs.1 00,000. After some time the price of Hubco drops from Rs50 per share to Rs.42 per share whereas PTC's share price rises from Rs 40 per share to Rs. 42 per share. The value of total investment will drop to Rs.92,000 as shown in the table below and the NAV/unit will drop to Rs9.2 from Rs.1O. If this were an open-ended fund and one had initially bought 100 shares at Rs.1O each (for Rs.1000) and if 
one decides now to redeem one's investment one will only get Rs.920 back from the mutual fund $(100 \times 9.2)$.

\begin{tabular}{lccccc}
\hline \multicolumn{1}{c}{ Co. Name } & $\begin{array}{c}\text { No. of } \\
\text { Investment }\end{array}$ & $\begin{array}{c}\text { Purchase } \\
\text { Price }\end{array}$ & $\begin{array}{c}\text { Total } \\
\text { Investment }\end{array}$ & $\begin{array}{c}\text { Present } \\
\text { Mk Price }\end{array}$ & $\begin{array}{c}\text { Investment } \\
\text { Amount }\end{array}$ \\
\hline Hubco & 1000 & 60 & 60,000 & 50 & 50,000 \\
PTC & 1000 & 40 & 40,000 & 42 & 42,000 \\
Total Investment & $\mathbf{1 0 0 , 0 0 0}$ & & & & $\mathbf{9 2 , 0 0 0}$ \\
Total units of Fund & 10,000 & & & & 10,000 \\
NAV per unit (shr) & $\mathbf{1 0 . 0 0}$ & & & & $\mathbf{9 . 2 0}$ \\
\hline
\end{tabular}

\section{Open-End Vs. Close-End Mutual Fund}

Open-End Mutual Funds shares do not trade in the secondary markets. If an investor wants to sell his shares, then he will sell those shares back to the fund at current market price, and the company is obliged to buy those shares from the investors at that price. Current market price of Open-End Mutual Fund is equal to the Fund's Net Assets Value (NAV). Similarly, if anyone wants to buy the shares of Open-End Mutual Fund, he has to purchase the shares from the fund itself.

The shares of Close-End Mutual Funds are traded on stock exchanges, due to which the outstanding number of shares remains constant, unless the fund announces bonus shares or right shares to the existing shareholders. The market price of the share of Close-End Mutual Funds is determined by the demand and supply of the shares, and not by NAV. Throughout the world close-end funds have a tendency to trade at a small discount to their net asset value. However, in Pakistan the discounts are phenomenal, averaging 50 per cent. As the Pakistan stock market matures and fundamentals rather than sentiments become the driving force, we expect the market price of these funds to rise to trade closer to their net asset values 